\title{
OBITUARY
}

\section{Sir John Cumming}

Sir John Cumming, K.C.I.E., C.S.I., died in London on 9th March, 1958, in his ninetieth year. From 1887 until 1920, when he retired on grounds of health, he was a member of the Indian Civil Service. In 1909 he became a Secretary to the Bengal Government and in 1913 Chief Secretary. A few years later Lord Zetland (then Lord Ronaldshay) made him a member of the Executive Council of Bengal.

After retirement he became Vice-Chairman of the London School of Oriental and African Studies (1926-1946) and a member of the Council of this Society, which he joined in 1943, giving it the unobtrusive service that was so characteristic of him.

His published works include Murray's Handbook for India, 1924, Modern India, 1931, Political India, 1932, and Revealing India's Past (1939).

As the Marquess of Zetland has remarked: "He was endowed with an innate modesty which tended to mislead a casual observer as to the extent of his abilities."

\section{Professor E. D. Edwards}

Professor Evangeline Dora Edwards, Lit.D., daughter of the Rev. John Edwards, died in London on 29th September, 1957, in her sixty-ninth year. After spending nine years in China she joined the staff of the School of Oriental Studies as a Lecturer in 1921, becoming a Reader in 1931 and Professor of Chinese in 1939.

Her most important work was her Chinese prose literature of the T'ang period, London, 1937-8. In 1940 she wrote a volume on Confucius. She published also two anthologies of translations and passages on China and the Far East and South-East Asia, the Dragon Book (1938) and Bamboo, Lotus, and Palm (1948). But devotion to multifarious duties at the School of Oriental Studies prevented her from prosecuting her Chinese studies. Her last service was to act as Head of the Percival David Foundation. Unvarying kindness and consideration won her the affection of her colleagues and many students.

She joined this Society in 1925 and served it both as Honorary Secretary and a Member of Council. 